\title{
REVIEW
}

\section{Can Caribbean coral populations be modelled at metapopulation scales?}

\author{
P. J. Mumby* \\ Centre for Tropical Coastal Management Studies, Department of Marine Sciences and Coastal Management. \\ Ridley Building, The University, Newcastle-upon-Tyne NE1 7RU, United Kingdom
}

\begin{abstract}
Understanding and predicting the connectivity of coral reef organisms linked by larval dispersal is a key goal of tropical coastal ecosystem science and management. As oceanographers make advances modelling transport processes between reefs, ecologists should be prepared to embrace the population dynamics of organisms at larger metapopulation scales. A metapopulation is demographically closed but contains multiple open local populations. Metapopulation models of coral dynamics would aid the identification of larval source and sink areas and help identify the boundaries of demographically closed populations. Metapopulation models would also aid the understanding of species extinctions and help formulate transboundary management strategies to conserve ecosystem function. Existing metapopulation models are not spatially realistic or proven to represent physical and biological processes at appropriate spatial and temporal scales. Before more realistic alternatives can be established, further research is needed into (1) the larval transport between reefs (i.e. the coupling of reef-scale and oceanic models of water circulation, the pre-settlement mortality rates of larvae, and larval mobility in the water column), (2) the influence of larval supply on coral population dynamics at local (10s of kilometres) scales (i.e. processes of settlement behaviour, post-settlement mortality, and the pre-emption of space by algae), and (3) processes affecting the net fecundity of local populations (i.e. interactions of colony size, partial mortality rate, competition with algae, and the influence of habitat, physical disturbance, herbivore pressure, nutrification and sedimentation).
\end{abstract}

KEY WORDS: Coral - Metapopulation - Population dynamics - Model - Scale - Remote sensing Connectivity

\section{INTRODUCTION}

Empirical evidence and theoretical considerations show unequivocally that large-scale processes must be embraced if we are to understand the population dynamics of organisms which have a pelagic phase during their life history (Caselle \& Warner 1996, Cornell \& Karlson 1996, Hatcher 1997). At large scales, such organisms (e.g. sessile invertebrates, reef fish) form populations whose dynamics are open at the local scale (Warner \& Hughes 1989, Gilpin \& Hanski 1991, Gaines \& Lafferty 1995, Alexander \& Roughgarden $1996)$ but demographically closed at some larger

•E-mail: p.j.mumby@ncl.ac.uk metapopulation scale beyond which the effective dispersal of larvae by oceanic and coastal currents ceases (Roughgarden \& Iwasa 1986). In a coral reef context, the hydrological connectivity of local fish and invertebrate populations has important implications for the science underpinning coastal (Done et al. 1996) and fisheries management (Roberts 1997). For example, some coral reefs may be net sources of larvae to reefs downstream, whereas other reefs may be net larval sinks, reliant on sites upstream for their larval supply (Roberts 1997). Further, hydrological connectivity between ecosystems can lead to the transfer of pathogens, pollutants, nutrients and sediments, and therefore poor agricultural practices can affect coral reefs downstream (e.g. Nowlis et al. 1997) and possibly beyond international boundaries. 
In a paper on the transport envelopes of fish larvae between Caribbean reefs, Roberts (1997) identified groups of countries with interconnected coastal fish populations, suggesting that cooperative management was vital to sustain recruitment levels in the fishery. Whilst Roberts' (1997) assumption of passive larval dispersal by ocean currents has been criticised (Bellwood 1998, Sale \& Cowen 1998), the need for models of larval transport between reefs is uncontested. Larval transport may be a highly localised phenomenon where marine larvae become entrained within coastal circulation (Olson 1985, Sammarco \& Andrews 1988, Black et al. 1991, Black 1993) or where larvae are competent to settle soon after release (Carlon \& Olson 1993). However, at the scale of inter-reef connectivity in the Caribbean, where entrained larvae may exist in the plankton for weeks to months (Roberts 1997), the destination of larvae is strongly influenced by mesoscale variability (e.g. Lee et al. 1994) at scales of several hundred kilometres and months to a year (Mooers \& Maul 1998).

Reviewing oceanic circulation in the Intra-Americas Seas (IAS), Mooers \& Maul (1998) concluded that the present understanding of mesoscale oceanic variability is confined to a few well-studied regions (e.g. Florida, the Gulf of Mexico) but by applying process-based theory of circulation from these areas to less studied areas of the IAS, and making field verifications, predictive simulation models of IAS circulation will be possible. It is conceivable, then, that ecologists may soon have better information on the transport envelopes between reefs which potentially provides new insight into the population dynamics of organisms which have a planktonic stage.

A number of attempts have been made to model the metapopulation dynamics of both sessile (Iwasa \& Roughgarden 1986, Roughgarden \& Iwasa 1986. Possingham \& Roughgarden 1990, Preece \& Johnson 1993. Stone et al. 1996) and mobile (Man et al. 1995) marine organisms, but, as I will show later, none are suitable for modelling fish or invertebrate metapopulations distributed across reefs of the Caribbean. Metapopulation models were originally conceived by Levins (1970) to describe a structureless network of conspecific populations whose dynamics were dominated by extinction and colonisation. This extreme view of metapopulations has been modified extensively in the last $30 \mathrm{yr}$ (see Gilpin \& Hanski 1991) with the emergence of spatially realistic models of real patch networks whose populations may be depressed rather than driven extinct (see Hanski \& Simperloff 1997). A spatially realistic metapopulation model of scleractinian coral populations would be highiy appropriate for investigating large-scale issues of reef sustainability such as the identification of larval source and sink areas (see also Ogden 1997), investigating the vulnerability to and potential recoverability from major disturbances of local populations of sessile organisms, and identifying the boundaries of demographically closed populations (Grosberg \& Levitan 1992). Realistic metapopulation models would also predict the effects of habitat loss on community structure and diversity (Stone 1995, Cornell \& Karlson 1996), improve understanding of the competitive interactions between species or taxa with different dispersal abilities (Gaines \& Lafferty 1995). and predict the long-term effects of massive bleaching events (Brown 1997) and disease outbreaks. Ultimately, the predictions of such models would improve the formulation of transboundary management strategies to conserve ecosystem function.

In this paper I discuss the challenge of building population models suitable for predicting the metapopulation dynamics of scleractinian corals on Caribbean reefs. My intention is to highlight ecologlcal questions for empiricists and modellers in order to take advantage of the metapopulation scales made possible by advances in oceanography. I begin by describing the design and objectives of metapopulation models and then review the problems and considerations which need to be embraced using interdisciplinary studies. I do not discuss in detail. the difficulties of modelling IAS circulation since this has been reviewed elsewhere (e.g. Mooers \& Maul 1998),

\section{DESIGN AND OBJECTIVES OF METAPOPULATION MODELS}

The design of a metapopulation model will clearly depend on the question(s) being asked, and metapopulation models have biogeographic, genetic, evolutionary, and ecological interpretations (Hanksi \& Gilpin 1997, Hubbell 1997). Jackson et al. (1996) provide an evolutionary example for corals by describing how the turnover of Caribbean coral species during the early Pleistocene may have resulted from local extinction at latitudinal extremes after a rapid fall in sea level greatly reduced the number of available patches for cold-intolerant species. Jackson et al. (1996) referred to the metapopulation model of Nee \& May (1992) which predicted that species of lower colonisation potential would go extinct first as available habitat decreases. The limited evidence supports this theory in that the life history strategy of acroporid corals, which replaced pocilloporids in terms of dominance, favours fast growth and the ability to track changes in sea level (Chappell \& Polach 1991). Spatially realistic metapopulation models would also help clarify the roles of dispersal, disturbance frequency, and interspecific competition in explaining the apparently ubiquitous 
distribution of coral species throughout the Caribbean on ecological and some geological time scales (Karlson \& Cornell 1998)

I focus here, however, on ecological time scales of years to decades which are relevant to the population dynamics of many reef corals (Hughes 1996), although the longevity of some massive corals (e.g. Montastraea annularis) may exceed 200 yr (Hudson et al. 1994). Through their zooxanthellae symbionts, scleractinian corals fix carbon which is principally directed towards bioconstruction of the reef framework and trophic pathways throughout the ecosystem (for details see Dubinsky 1990, Johnson et al. 1995, Done et al. 1996. Opitz 1996, Hatcher 1997). Major reef-building corals, such as Montastraea spp., Siderastrea siderea, Acropora spp. and Diploria spp., generally attain large size and have a broadcasting life history strategy (Szmant 1986) which is relevant to metapopulation concepts of open or partially open local populations. The acroporids are probably an exception, however, due to their high rates of asexual reproduction by fragmentation (Highsmith et al. 1980, Neigel \& Avise 1983), which for A. palmata can account for two-thirds of the colonies on a reef (Highsmith 1982). The aim here would be to predict temporal changes in the abundance and sizefrequency distribution of corals within local populations and their implications for reef function at local and metapopulation scales. I focus on this aspect of metapopulation modelling and discuss the definition of spatial scales for the model and some of the difficulties in modelling both the planktonic and benthic model components.

\section{DEFINING SPATIAL SCALES OF LOCAL AND METAPOPULATIONS OF CORALS}

A metapopulation model requires at least 2 spatial scales: the local populations (Fig. 1) and the larger metapopulation.

Gaines \& Lafferty (1995) defined open local populations as existing where Migration of individuals among local populations is common. In the case of marine species with long lived pelagic larvae, immigration is the only way that local populations increase in size. In such extreme open populations, local reproduction does not affect local population dynamics'. However, this definition is at odds with reef systems

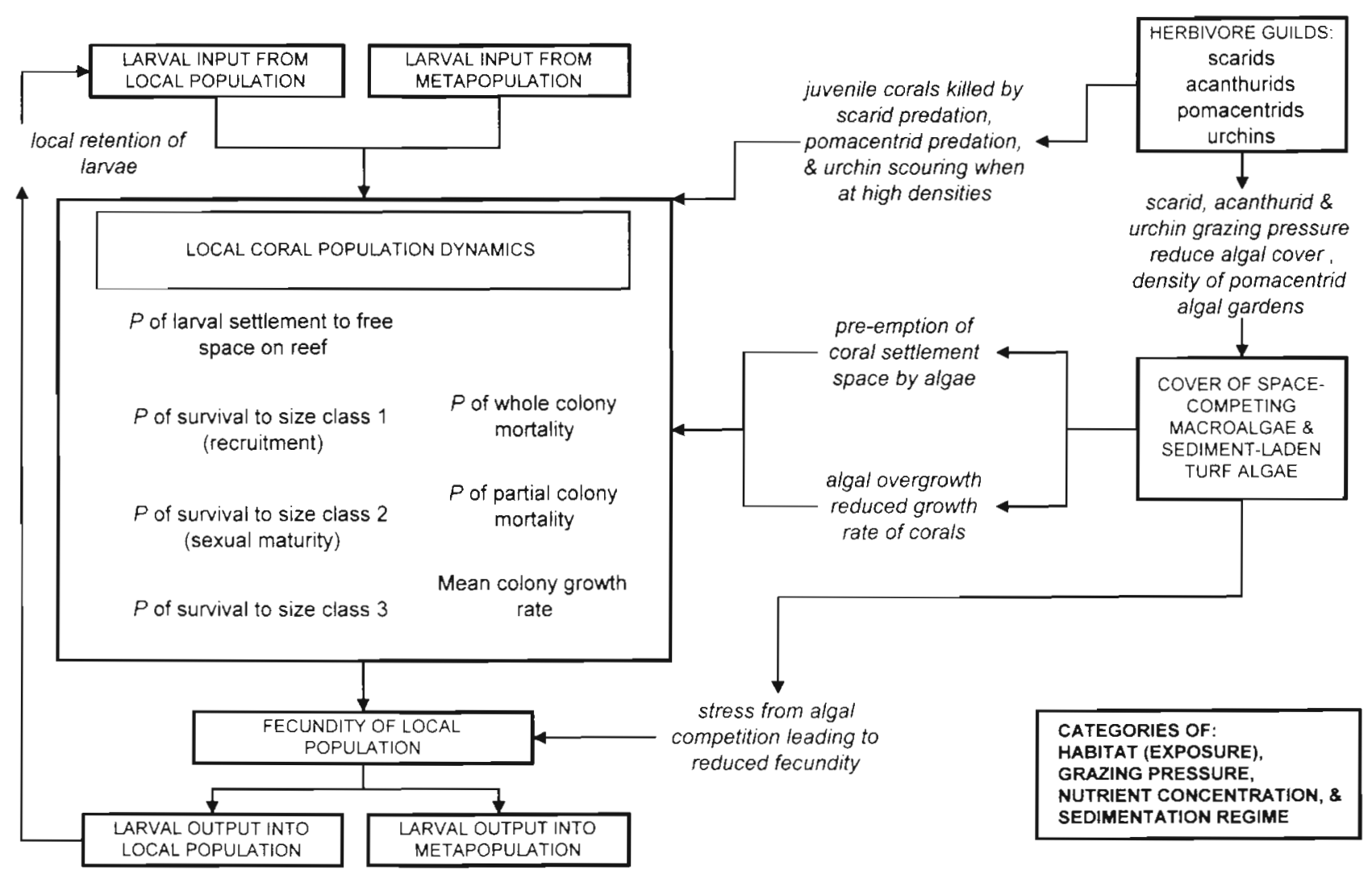

Fig. 1. Representation of processes affecting local coral population dynamics showing larval exchange with the metapopulation. The model should be parameterised for varying categories of habitat (exposure), grazing pressure, nutrient concentration and sediment regime which are putatively the major external controls affecting the coral population dynamics. $P$ : probability 
with high local retention of larvae (i.e. where local reproduction may affect local population dynamics) and a more appropriate definition can be extracted from Hanski \& Simperloff (1997), who state that 'individuals practically share a common environment', which might refer to local levels of the most important processes controlling coral population dynamics at a practicable scale for modelling (Fig. 1). These processes are described in detail later but may include herbivory (fishing intensity and Diadema antillarum densities), suspended sediment regime, nutrient concentration, physical wave exposure and potential larval supply (proximity to nearest source of larvae).

Choosing an appropriate spatial scale to represent local populations is difficult because of (1) the paucity of geographic data on local processes (e.g herbivory) and reef attributes such as size, and (2) the computer tractability of simulations (i.e. the maximum number of local populations that can be simulaled, depending on the complexity of the model). Oceanic models can predict circulation (and therefore estimate larval supply) on a grid representing $20 \mathrm{~km}$ by $20 \mathrm{~km}$ cells (Gao \& Mooers 1996, cited in Mooers \& Maul 1998), and the World Conservation Monitoring Centre (WCMC) has estimated coral reef area at a resolution of $1 \mathrm{~km}^{2}$ (Spalding \& Grenfell 1997). However, there is little consistency in definition of 'coral reef' in the WCMC coverage and future coral reef mapping initiatives at local and regional scales should adopt a standardised classification scheme or protocol (Mumby \& Harborne 1999). Where water conditions permit (ca horizontal Secchi distance $>15 \mathrm{~m}$ and depth $<20 \mathrm{~m}$ ), estimates of coral reef area and distribution can be improved using satellite remote sensing. Mumby et al. (1997) demonstrated that the satellite-borne sensor Landsat Thematic Mapper provides the most cost-effective means of making detailed ( $<30 \mathrm{~m}$ pixel size) maps of coral reef distribution over hundreds of kilometres. Each image covers approximately $185 \mathrm{~km} \times 185 \mathrm{~km}$ and the creation of an accurate (thematic accuracy ca $70 \%$ ), region-wide coverage is feasible. Satellite images of coral reefs also provide a semi-quantitative distribution of suspended sediment concentration in surface waters (Clark 1993) which may help make a crude categorisation of sedimentation at the scale of local coral populations. Similarly, coarse levels of eutrophication may be inferred from a time series of chlorophyll a concentrations within coastal areas, which can now be obtained synoptically throughout the IAS using data from the satellite-borne sensor SeaWiFS (Sea-viewing Wide Field-of-view Sensor; for overview, see Acker 1997).

In short, further remote sensing is required to develop a grid-based model of coral reef distribution, coral reef area, and physical environmental conditions (e.g. water quality). This will need to be augmented by additional field data on ecological processes (e.g. herbivore biomass) and reef status (e.g. size-frequency distribution of corals) and might be partly achieved (1) by review of the descriptive literature on coral reef communities (particularly the Atoll Research Bulletin), (2) by interaction with REEFBASE, the global database on coral reef status (McManus \& Ablan 1997), (3) through regional networks of coastal ecosystem monitoring such as CARICOMP (Caribbean Coastal Marine Productivity: Ogden et al. 1997, Woodley et al. 1997), and (4) using the results of rapid reef assessment surveys focused on coral mortality, herbivore guilds and algal functional groups (e.g. the Atlantic \& Gulf Reef Assessment exercise, R. N. Ginsburg pers. comm.). On a cautionary note, however, the predictions of models can only be as good as the data they are based on and therefore sensitivity analyses should be carried out to examine the influence of say the standard error of local coral cover estimates on the predictions of the model.

Given the uncertainty in defining the extent of local populations, it may prove more realistic to derive probabilistic boundaries to metapopulation size rather than attempt to describe the absolute extent of any metapopulation. For example, transport envelopes could be estimated representing the probability that reefs receive $10,30,50$, and $100 \%$ of propagules from within the envelope.

\section{THE PLANKTONIC COMPONENT OF THE METAPOPULATION MODEL}

Several marine metapopulation models have no spatial structure and make the simplifying, but clearly inappropriate, assumption of complete mixing of larvae and that patches have equal access to the larval pool (e.g. Iwasa \& Roughgarden 1986, Roughgarden \& Iwasa 1986, Man et al. 1995, Stone et al. 1996). An appropriate model of larval dispersal needs 2 principal components: (1) the geographic transport of larvae between reefs, which depends on the velocity and vertical stratification of oceanic and coastal currents, and the motility of larvae, and (2) the survivorship of larvae over time.

\section{Geographic transport of larvae in coastal and oceanic currents}

The swimming speeds of coral planulae are orders of magnitude less than those of oceanic currents (Hodgson 1985, Carlon \& Olson 1993) so assumptions of passive dispersal by oceanic currents may be valid in general (Harrison \& Wallace 1990). However, variations in 
wind velocity will greatly affect dispersal (Willis \& Oliver 1988) and the buoyancy of larvae tends to decrease with time (Babcock \& Mundy 1996), meaning that vertical mixing in the water column should be taken into account. Existing oceanic circulation models incorporate vertical structure in the water column by using multiple depth strata (ca 25), principally focused at the ocean surface and near the benthos (C. N. K. Mooers pers. comm.).

While existing oceanic models of IAS mesoscale circulation have good vertical resolution, one of the main problems in predicting the supply of larvae to a reef (and indeed larval output from a reef) is the reconciliation of horizontal scales between these oceanic models, which have a minimum grid size of ca $20 \mathrm{~km}$ (Mooers \& Maul 1998), and the vertically integrated fluid dynamic models used to predict circulation around coral reefs, which typically have grid sizes of hundreds of metres (e.g. Black 1993, Kraines et al. 1998). Preece \& Johnson (1993) created a cellular automaton model of coral populations of the central Great Barrier Reef (see also Johnson \& Preece 1993) and used larval retention coefficients, predicted by vertically integrated fluid dynamic models (Black et al. 1990), to simulate connectivity. Although the model was not spatially realistic (e.g. it did not include realistic reef shapes, sizes, or hydrological conditions), this method may be approprid.te for bridging the scales of oceanic and reef circulation models but further modelling activities are required to characterise larval retention regimes for generic reef shapes, areas, depths, weather conditions and circulation parameters (sensu Black 1993). Further, the disparity in spatial scales between oceanic and reef circulation models may be reduced in the foreseeable future by nesting high resolution grids within oceanic models, possibly attaining resolutions of 1 to $5 \mathrm{~km}$ (C. N. K. Mooers pers. comm.).

\section{Survivorship of larvae in the plankton}

Broadcast planulae develop for a minimum of 4 to $6 \mathrm{~d}$ prior to becoming competent to settle and metamorphose (see review by Harrison \& Wallace 1990) and settlement must take place within 3 to $4 \mathrm{wk}$ or else planulae will have insufficient energy reserves to metamorphose (Richmond 1988). However, virtually nothing is known about larval mortality rates other than mortality may increase whilst in the vicinity of reefs, mainly due to planktivorous reef fish (Hamner et al. 1988, Westneat \& Resing 1988) and that the larvae of brooding Caribbean corals (e.g. Agaricia agaricites, Porites astreoides, and Siderastrea radians) are highly palatable to damselfish and wrasse (Lindquist \& Hay 1996). Recent developments in larval genetics, permit- ting molecular tagging (see comments by Ogden 1997), may, in future, provide insights into larval behaviour. Experiments may be designed where tagged larvae are released into natural systems whose flow regimes are well studied and periodic plankton sampling should aim to differentiate larval mortality rates from losses of plankton due to diffusional and advective transport processes.

\section{THE LOCAL POPULATION COMPONENT OF THE METAPOPULATION MODEL}

The following section reviews current understanding of coral population dynamics and the scales of causative processes. From a metapopulation modelling perspective, it is critical to understand the processes governing the recruitment of corals to a population (i.e. relationship between larval supply and recruitment), and the net fecundity (larval output) of the population (Fig, 1).

\section{Larval settlement}

Models of barnacle metapopulation dynamics along the coast of California (Possingham \& Roughgarden 1990, Alexander \& Roughgarden 1996) use diffusive and advective models of larval transport and estimates of larval mortality rate to predict the supply of larvae to suitable habitat. Larval settlement is then manipulated using a coefficient. Unfortunately, there are no benchmark estimates of larval settlement rate available to reef ecologists since the processes affecting coral recruitment, namely, larval supply, settlement behaviour, the availability of free space, and post-settlement mortality, are poorly understood (Babcock \& Mundy 1996).

The settlement behaviour of planulae has been studied intensively but many observational studies are inconclusive because of the difficulties in inferring active substratum selection when stochastic larval supply and patchy post-settlement mortality are not recorded. In general, however, larvae appear to prefer rough surfaces (Lewis 1974, Carleton \& Sammarco 1987. Smith 1997) which may enhance attachment (see review in Harrison \& Wallace 1990). Chemical cues are known to induce larvae of some genera (e.g. Aganicia) to settle on encrusting red algae (Morse et al. 1988); other species (e.g. Favia fragum) prefer to settle near conspecifics (Lewis 1974); whilst others are inhibited by secondary metabolites from other taxa such as soft corals (Maida et al. 1995). Settlement characteristics may be highly species-specific (Morse et al. 1988, Carlon \& Olson 1993). 
In a unique experimental study, Babcock \& Mundy (1996) investigated the survivorship and settlement behaviour of larvae from the broadcast spawning corals Platygyra and Oxypora, whose adult populations are stratified by depth. Adult patterns of distribution were not attributable to depth-related mortality rates of settled larvae, suggesting that either the supply of larvae differs with depth for the 2 species or the mortality rates of larger corals are depth-dependent and species-specific. Another important result of the study was that no microhabitat had persistent advantages in terms of recruit survivorship. For the first 4 mo after larval attachment, survivorship was highest for recruits attached to under surfaces where sediment accumulation was reduced. However, this pattern was reversed after 4 mo because the higher growth rate of corals attached to vertical and upper surfaces provided an escape from mortality due to larger size (sensu Hughes \& Jackson 1985). Thus, Babcock \& Mundy (1996) concluded that there may be no single optimum settlement orientation for larvae as survivorship varies with habitat, sediment regime, and coral size.

Sedimentation appears to be particularly important in determining early mortality at both microhabitat scales (Maida et al. 1994, Gleason 1996) and reef scales (Hunte \& Wittenberg 1992). Sediments can affect larval settlement directly by preventing secure attachment and indirectly by altering larval settlement behaviour. Increased water turbidity could make more cryptic habitats too dark, either increasing mortality rates in these refugia (due to decreased coral growth rate) or forcing larvae to settle on more exposed upper surfaces where sediment levels or grazing intensity may be higher, possibly increasing juvenile mortality rates (Maida et al. 1994).

The effects of nutrification (increased ambient nutrient concentrations on coral settlement are only beginning to emerge. Ward \& Harrison (1997) manipulated nitrogen and phosphorus concentrations on adults and larvae of Acropora longicyathus and found that increases in both nutrients reduced the settlement of spat and that their effects were synergistic. The mechanisms by which elevated nutrients prevent settlement are not understood but may involve blooms of cyanobacteria which release toxins to prevent larval attachment. Conversely, Ward \& Harrison (1997) found that larvae released from adults which had been incubated in a nitrogen-rich environment showed high levels of settlement when released in ambient seawater. Corals are nitrogen-limited so the settlement success of larvae developing in nitrogen-rich conditions might be attributable to a release from this limitation enabling greater amino acid production which confers greater protection from ultraviolet radiation. Larvae released from eutrophic reefs may therefore have greater survivorship than those from oligotrophic reefs whereas larval settlement on eutrophic reefs may be severely reduced. Whether these patterns hold for other species remains to be seen.

\section{Post-settlement mortality and recruitment}

Empirical data on coral recruitment in the Western Atlantic are unequivocal in the numerical dominance of recruits from brooding species and paucity of recruits from species which broadcast their gametes (Bak \& Engel 1979, Rogers et al. 1984, Hughes 1985, Smith 1992, 1997). More experimental work is needed to explain the low levels of recruitment observed for the latter group (i.e. to assess the relative importance of larval supply, settlement behaviour, and postsettlement mortality).

In general, recruitment of corals has been shown to be space-limited (i.e. positively correlated to free space available) in Jamaica (Hughes 1985) and the Great Barrier Reef (Connell et al. 1997), but recruitment also shows great temporal variation (Gleason 1996, Connell et al. 1997) and spatial variability on a wide range of scales including continental shelves (Sammarco 1991), between reefs (Fisk \& Harriott 1990), and within sites (Babcock 1989, Smith 1992, Baird. \& Hughes 1997). Available empirical evidence suggests that post-settlement mortality in corals is high (Smith 1997), but the density dependence (or otherwise) and scale dependence of such processes are poorly understood and difficult to infer from observational studies (Caley et al. 1996). This difficulty arises throughout benthic ecology because observations of persistent and variable ageclass strength in a population, which are usually inferred to indicate density-independent mortality (e.g. Victor 1986), may occur in the presence of density-dependent mortality (Holm 1990). Further, variable post-recruitment mortality may obscure the relationship between recruitment and year-class strength even in the absence of density-dependent mortality (Warner \& Hughes 1989). Caley et al. (1996) point out that experiments should manipulate entire cohorts over a number of years in order to examine the effects of recruitment on age distributions and overall population size.

The feeding activities of herbivores can have positive and/or negative effects on coral recruitment (Fig 1). Dense aggregations of Diadema (Sammarco 1980, Rylaarsdam 1983) and intense fish grazing (Bak \& Engel 1979, Sammarco 1991, but see Birkeland 1977) may overgraze the substratum preventing successful coral recruitment. Conversely, Birkeland (1977) found that intermediate grazing pressure on Caribbean reefs 
promoted coral settlement by removing fouling turf and macroalgal canopies, and Morse et al. (1988) suggested that grazers may facilitate establishment of specific (though unidentified) red coralline algae, which in turn promotes settlement of Agaricia humilis through chemical cues. The adaptive significance of settlement cues from coralline algae and direct grazing effects on recruit survival have not been fully explored. Studies of feeding selectivity by the parrotfish Sparisoma viride, which is capable of killing coral recruits, revealed an active avoidance of coralline algae (Bruggeman et al. 1994) but, again, the coralline species concerned were not identified. If the same coralline species were avoided by parrotfish and induced settlement of invertebrate larvae, one might investigate the importance of parrotfish grazing as a selective agent favouring the (co)evolution of larval settlement cues from coralline algae.

Modelling and empirical studies are needed to assess the effects of major space occupiers on coral recruitment. It is clear from the discussion above that larval settlement is inhibited by macroalgae and sediment-laden turf algae (Fig. 1), yet very little is known of the spatio-temporal dynamics of these space competitors and their effects on the survivorship of corals. Several issues need to be resolved for a clearer understanding. First, what effect does algal overgrowth exert on the survivorship of coral recruits, and how does survivorship vary with (1) the species and biomass of alga, (2) the duration of overgrowth, and (3) the size of coral recruit? Second, what are the spatial dynamics of algal cover in relation to its effect on the survivorship of recruits? In terms of recruitment dynamics and the role of available space, the 2 questions are intimately linked. For example, imagine that a 6 mo old recruit could withstand macroalgal overgrowth for 2 mo without a significant decline in survivorship, and that the coral must grow for 2 yr to become large enough to escape algal-induced mortality. Then the appropriate question for studies (and models) of recruitment dynamics would be: what is the total percent cover of substratum experiencing macroalgal overgrowth for periods less than 2 mo during a $2 \mathrm{yr}$ period? Thus, the role of algal cover in preventing recruitment may be underestimated by studies estimating average algal cover at reef or site scales because, while average cover may appear to be stable at this scale, the total area covered by algae for 2 mo periods may differ markedly. De Ruytner van Stevenick \& Breeman (1987) studied the cover of Lobophora variegata at a depth of $25 \mathrm{~m}$ in Curaçao and found no significant changes in cover at the reef scale but cover in individual quadrats, measuring 11 by $16 \mathrm{~cm}$, varied from 10 to $90 \%$ during the same period (1 yr). Clearly, spatio-temporal scales of algal patch dynamics must be studied in greater detail, and in relation to the principal structuring processes of different herbivore guilds (Hay \& Taylor 1985, Carpenter 1986, Foster 1987, Steneck 1989), potential productivity and regrowth capability (Steneck \& Dethier 1994), and detachment by physical disturbance (Carpenter 1986).

Ultimately, empirical and modelling methods might try to identify the 'recruitment potential' of reefs with various structural complexity (see Steneck 1993), algal cover, grazing regime, wave exposure, and sediment regimes. I define the recruitment potential of a reef as the probability that a competent larva reaching a reef will settle and reach recruit size (ca $1 \mathrm{~cm}$ ), but more appropriate definitions may be prompted by further studies. Models should be spatially explicit in order to incorporate the complex spatial interactions of the aforementioned processes, but emphasis must be placed on modelling the simplest set of parameters capable of affecting recruitment dynamics. Model predictions should aim to describe a probability distribution of recruitment levels for reefs experiencing different intensities of biological and physical processes. For example, the recruitment potential of an exposed forereef with many large herbivorous parrotfish, few Diadema, and low sedimentation rate may be 0.02 (SE 0.1 ) but only 0.001 (SE 0.04) where herbivory is reduced. Burrows \& Hawkins (1998) describe a cellular automaton approach to modelling algal patch dynamics on temperate rocky shores and this principle might be adapted by reef ecologists (see also Caswell \& Etter 1993).

\section{Coral growth and mortality}

The growth rates of most major reef-building corals (e.g. Montastraea annularis) decrease with depth (Highsmith et al. 1983, Huston 1985) although Bosscher \& Meesters (1993) found growth to be light-saturated to a depth of $15 \mathrm{~m}$ and then sharply light-limited to $30 \mathrm{~m}$. Juvenile growth rates are high (van Moorsel 1988) and, although growth can be indeterminate (Sebens 1987), relative growth rate decreases with increasing coral size and age partly due to increased rates of partial colony mortality and possibly by greater energetic investment in sexual reproduction (Hughes \& Connell 1987). Bleaching events can cease coral growth even in large corals such as Montastraea spp. (Goreau \& Macfarlane 1990) but the anticipated deleterious effects of nutrification and sedimentation on growth rate are less clear.

Tomascik \& Sander (1985) found that eutrophication generally decreased the growth rate of Montastraea annularis in Barbados but that suspended particulate matter (SPM) could have variable effects on growth 
depending on concentration. At intermediate SPM concentrations, corals may derive nutrients from particulate matter, whereas high SPM concentrations may be deleterious by smothering polyps and reducing light availability to zooxanthellae. Increased nutrient concentrations can have indirect effects on coral growth rate (1) by promoting the cover of space competitors including macroalgae (Littler et al. 1993) and sponges (Wilkinson 1987, Aerts \& van Soest 1997) which potentially increases the incidence of competitive interactions and reduces growth rate (Tanner 1995), and (2) by promoting phytoplankton blooms which reduce the transmission of light to the benthos, thus reducing rates of photosynthesis (D'Elia \& Wiebe 1990). Direct effects of nutrients on coral growth rates are difficult to summarise because of the variation in nutrient concentration, application frequency, and duration of manipulative experiments. It would appear, however, that increased nitrogen can decrease the translocation of photosynthates from zooxanthellae to host thus reducing calcification rates (McGuire \& Szmant 1997, Steven \& Broadbent 1997) and that phosphorus may interfere with calcification by acting as a crystal poison (Hoegh-Guldberg et al. 1997).

Many metapopulation models (e.g. Caswell \& Cohen 1993. Tilman et al. 1994, Man et al. 1995, Stone et al. 1996) assume that disturbance leads to complete extinction of species on a patch but, during ecological time scales, such severe effects of disturbance are not appropriate for open populations of marine organisms which may show greater resistance to extinction (Caley et al. 1996, Connell et al. 1997). A more suitable model would allow local populations to be depressed but rarely driven to extinction. Mortality rates of adult corals are principally size-dependent (Hughes \& Jackson 1980, 1985, Hughes \& Connell 1987, Meesters et al. 1997), and to some extent age-dependent (Hughes 1984, Bak \& Meesters 1998). Whole colony mortality is greatest for small corals whereas the incidence of partial colony mortality from various biological (e.g. parrotfish grazing, disease) and physical (e.g. abrasion) sources increases with colony size (Hughes \& Jackson 1985, Bak \& Meesters 1998). Bak \& Meesters (1998) studied the partial mortality of massive corals in Curaçao at shallow sites of 6 to $10 \mathrm{~m}$ depth. They concluded that the modal size frequency class (on logarithmic axes) of each species might constitute a critical colony size where the relative importances of whole and partial colony mortality are reversed. Whether this result is site-specific is uncertain, but, if true, may help parameterise models of coral population dynamics by distinguishing the incidence of whole colony and partial colony mortalities (Fig. 1).

At larger spatial scales, storm and hurricane damage is highly patchy (Woodley et al. 1981, Edmunds \& Wit- man 1991, Witman 1992, Bythell et al. 1993a, b, Rogers 1993). For example, the effects of Cyclone Ivor on the Great Barrier Reef were patchy at scales of tens to hundreds of metres within $50 \mathrm{~km}$ of the 'eye' of the storm (Done 1992). With the exception of shallow water acroporids, large reef-building massive corals tend to be more resistant to storm damage than smaller encrusting species (Jackson \& Hughes 1985) although the strength of coral attachment to the substratum is predicted to be the main factor determining dislodgement rates (Massel \& Done 1993). Models of the effects of storms on reefs (e.g. Hughes 1984, Andres \& Rodenhouse 1993) and empirical studies (e.g. Hughes 1989 Done 1992, Witman 1992, Connell et al. 1997, Lirman \& Fong 1997, Rogers et al. 1997) are unequivocal in pointing out the importance of considering the historical regime of disturbances when attempting to predict or interpret the effect of any individual disturbance (Hughes 1989). For example, the negative effect of Hurricane Hugo in 1989 on coral cover in St. John (U.S. Virgin Islands) was so severe that more recent hurricanes (Luis and Marilyn) in 1995 did not, on average, depress coral cover further (Rogers et al. 1997).

It may be impossible to simulate hurricane-induced mortality events at reef scales because of the stochastic spatio-temporal patchiness in severity and frequency of disturbance (Done 1992). However, small-scale (10s of kilometres) stochastic modelling with depressed (damaged) coral populations simulated at scales of hundreds of metres (see above) may predict the probability distribution of various small-scale outcomes over a given time interval (e.g. net change of coral size-frequency distribution at kilometre scales). Probabilistic outputs would then be inserted into larger-scale models (i.e. the representation of local populations within the metapopulation) in an attempt to bridge the gap in scale between models. Conceptually, the metapopulation model may then simulate the recovery of coral populations from hurricanes where the effects of each hurricane are chosen pseudo-randomly from the probability of small-scale outcomes. The problem of simulating major disturbances may be reduced at evolutionary and geological temporal scales. Treml et al. (1997) reconstructed the paths of hurricanes in the Lesser Antilles over the past 500 yr and found that the spatial distribution of hurricane paths was not random at century scales but the incidence of individual storms is unpredictable.

\section{Intra- and intertaxon competitive interactions}

Since the die-off of Diadema antillarum in 1983-94 (Lessios et al. 1984) some Caribbean coral reefs may have undergone a phase change in community struc- 
ture toward greater macroalgal biomass and often to the detriment of coral populations (De Ruytner van Stevenick \& Bak 1986, De Ruytner van Stevenick \& Breeman 1987, Hughes et al. 1987, Lessios 1988, Levitan 1988, Carpenter 1990, Hughes 1994, Bak \& Nieuwland 1995). At a regional scale, the importance of bottom-up (nutrification; Lapointe 1997) versus top-down (reduced herbivory; Hughes 1994, 1996) explanations for phase changes remains contentious, although the large spatial scale, sequence, and nature of changes would tend to support the latter hypothesis (with local exacerbation by nutrification and historical hurricane disturbances). In practice, these changes in reef community structure probably mean that macroalgae and turf algae are the dominant space competitors with coral colonies rather than other corals (Fig. 1; Rogers 1993). In Curaçao, De Ruytner van Stevenick et al. (1988) found that growth rates of the brown macroalga Lobophora variegata were reduced by $35 \%$ when in contact with small corals but that algal-coral overgrowth continued. In Australia, Tanner (1995) found that macroalgal competition reduced growth rates of (semi-)encrusting acroporid corals but not bushy (erect) pocilloporids. Further research is needed into the consequences of algal-coral competition, particularly when viewed at large spatial scales (10s of kilometres). For example, how is algal-coral overgrowth' mediated by the size, morphology, and species of coral, wave exposure, light intensity (depth), and nutrient concentration? Although interspecific competition between corals is typified by competitive networks (Buss \& Jackson 1979, Chornesky 1989, Lang \& Chomesky 1990) which have been modelled (Karlson \& Jackson 1981, Karlson \& Buss 1984), algal-coral competition may be more predictable, lending itself to the simpler approach of modelling competitive hierarchies (see metapopulation models by Caswell \& Cohen 1993, Stone et al. 1996)

\section{Coral fecundity}

The puberty size of corals is size-dependent (Soong 1993) and usually larger in species which broadcast rather than brood their larvae (Harrison \& Wallace 1990). Puberty sizes and fecundities in Caribbean corals are well known though varied even within species (Szmant 1991, Soong \& Lang 1992, Soong 1993). Population models need to investigate the interactions of puberty size, partial colony mortality, and stress on the overall fecundity of the local population of corals. Models will have to take account of the age of corals because matrices of size-frequency distribution cannot simply be multiplied by the appropriate size matrix for fecundity. A reproductively mature colony that is reduced below puberty size by partial colony mortality may still reproduce (depending on whether central reproductive areas of the colony remain intact), albeit with reduced fecundity (Hughes 1984, SzmantFroelich 1985).

More research is needed into the effects of stress on the proportion of gravid polyps per colony, their gonad density, and gamete production. Effects of nutrification and sedimentation on coral fecundity have not been extensively studied although both appear to suppress fertility (Kojis \& Quinn 1984, Tomascik \& Sander 1987). Competitive interactions also affect fecundity (Fig. 1). Tanner (1995) found that the fecundity of Acropora palifera on the Great Barrier Reef was halved when in contact with macroalgae. Szmant (1991), working on Montastraea annularis, found that zones of polyps (a few centimetres wide) were infertile if in contact with other macro-organisms due to the high defence and growth demands of these polyps. These are small-scale observations and their effects at larger scales are unknown, largely because of the ethical considerations in removing tissue from many colonies (A. M. Szmant pers. comm.) and the time required for histological analysis. Extensive observations during spawning events may be the only feasible means of seeking further insight into large-scale effects on fecundity.

\section{TESTING PREDICTIONS FROM METAPOPULATION MODELS}

A great limitation of modelling at large scales is the difficulty in testing predictions of the model, particularly since most empirical studies are conducted at relatively small scales (Gaines \& Lafferty 1995, Caley et al. 1996). One method of testing metapopulation-scale predictions is the reconstruction of well-documented large-scale phenomena such as the phase changes on reefs during last 2 decades (Hughes 1994). In future, long-term geographic trends in the dynamics of coral populations from regional monitoring programmes (e.g. CARICOMP; Ogden et al. 1997) may provide partial support for metapopulation model predictions. However, for reasons outlined earlier, it is inadvisable to infer specific demographic processes from data on adult population dynamics unless entire cohorts (including recruits) are monitored. There is still a paucity of data on recruitment levels on Caribbean reefs and future monitoring efforts might consider including such data.

Investigations of gene flow may shed light on estimates of population connectivity (Palumbi 1994, Shulman \& Bermingham 1995, Ayre et al. 1997). Although low levels of gene flow may indicate infrequent larval exchange, high levels of gene flow among sites do not 
necessarily imply high levels of larval exchange during ecological time frames because even low levels of larval exchange may maintain gene flow (Sammarco \& Andrews 1988). Generally, reef-dwelling invertebrates with limited pelagic dispersal have been found to have restricted gene flow (e.g. Ayre \& Dufty 1994, Burnett et al. 1995) whereas species with broadcastspawning or long-lived brooded larvae have higher gene flow due to greater inter-reef connectivity (e.g. Burnett et al. 1994. Ayre et al 1997). However, evidence is also emerging that gene flow may be restricted even in areas which are anticipated to have strong larval connectivity. Working on Acropora palifera and Pocillopora damicornis at One Tree Island, Australia, Benzie et al. (1995) found a 10-fold drop in gene flow between reef crest populations and those inhabiting lagoon and microatoll areas. Such genetic isolation is difficult to reconcile given the expected exchange of larvae across the reef crest during periods of inundation, which may suggest that (currently unknown) local selective forces may be responsible. A more extreme deviation of expected gene flow was recently reported for the Pacific giant clam Tridacna maxima where gene flow ran perpendicular to present-day ocean currents (Benzie \& Williams 1997). In some areas and for some taxa, dispersal events may be episodic so that measured gene flow may still reflect oceanic circulation patterns when sea levels were different to those today. A spatially hierarchical examination of genotypic variation in Caribbean corals is long overdue but, given the arguments made above, any interpretation of gene flow must have both ecological and geological perspectives.

\section{CONCLUSIONS}

The title of this paper asks whether Caribbean coral populations can be modelled at metapopulation scales. The answer is almost certainly 'Not yet'. Whilst some simple patch-extinction models (Nee \& May 1992. Tilman et al. 1994) may predict loss of species if their habitat is reduced, these methods best lend themselves to evolutionary studies involving loss of genera during geological time scales (e.g. Jackson et al. 1996, but see Stone et al. 1996). Despite attempts to represent coral reef connectivity on cellular automata (Preece \& Johnson 1993), no coral reef metapopulation model is spatially realistic or proven to represent physical and biological processes at appropriate spatial and temporal scales.

Understanding the role of spatio-temporal heterogeneity in physical and biological processes on population dynamics is a central goal of ecology (Levin 1992, Aronson \& Precht 1997). Patchy processes on coral reefs can lead to large-scale heterogeneity in ecosystem structure. For example, Edmunds \& Bruno (1996) found large variations in benthic community structure at kilometre scales around Jamaica, and Aronson \& Murdoch (1997), surveying coral community structure of forereefs throughout the Florida Keys, found greater variation at among-reef scales $(10 \mathrm{~km})$ than at sub-reef $(1 \mathrm{~km})$ and regional $(100 \mathrm{~km})$ scales. Throughout this paper, I have echoed the words of others and called for further empirical research into the spatial dependency of processes, most of which have been studied at small spatial and temporal scales. Spatial modelling will be instrumental in improving our understanding of the interactions of complex processes. Model simulations may, for example, seek to predict the recruitment potential of reefs with different physical and biological characteristics. While simulation modelling will fail to provide simple biological rules governing community structure (sensu Judson 1994), its strength may be an ability to predict the relative probabilities of particular ecological outcomes (e.g. success of recruitment) for inclusion in largerscale metapopulation models. Simplification of real ecosystems will have to be attempted where possible. Here, I propose a focus on major reef-building corals (except acroporids) which probably have more open. population dynamics than smaller species which brood their offspring. Although this abstraction ignores a significant component of many coral assemblages, it may simplify the model because massive reef builders tend to be long-lived and have moderately stable population dynamics (Hughes \& Jackson 1985, Bythell et al. 1993a).

Conceptually, local populations of corals would be represented in various 'phases' of community structure (Knowlton 1992), depending on local conditions of say grazing pressure and eutrophication, and the history of disturbance and recruitment. Further modelling and empirical studies are needed to understand the causative processes and stability of phase changes in community structure, with particular focus on the importance of larval supply, settlement and postsettlement processes. Only then will metapopulation scales of larval connectivity be interpreted and modelled meaningfully. However, even simple metapopulation models can exhibit complex behaviour (Gaines \& Lafferty 1995) so testing the internal workings and predictions of a more complex metapopulation model. may constitute the greatest challenge of all.

Acknowiedgements. I would like to thank Terry Hughes and the coral reef discussion group of James Cook University for their comments on an early draft of the manuscript, Bob Steneck for helpful discussions on the recruitment problems facing coral reefs, and Prof. Chris Mooers for providing insight 
into modelling circulation within the IAS. Pete Edmunds and 3 anonymous referees are thanked for their suggestions on a later draft of the paper. The author is funded by a NERC postdoctoral fellowship under the Earth Observation Science Initiative.

\section{LITERATURE CITED}

Acker JG (1997) SeaWiFS data available at the GSFC DAAC Backscatter 8:8-14

Aerts LAM, van Soest RWM (1997) Quantification of sponge/coral interactions in a physically stressed reef community, NE Colombia. Mar Ecol Prog Ser 148:125-134

Alexander SE, Roughgarden J (1996) Larval transport and population dynamics of intertidal barnacles: a coupled benthic/oceanic model. Ecol Monogr 66:259-275

Andres NG, Rodenhouse NI (1993) Resilience of corals to hurricanes: a simulation model. Coral Reefs 12:167-175

Aronson RB, Murdoch THT (1997) Coral faunas of the Florida Keys: a report on the Keyswide coral reef expedition. Dauphin Island Sea Lab Technical Report 97-001, Dauphin Island Sea Lab, Dauphin Island, AL

Aronson RB, Precht WF (1997) Stasis, biological disturbance, and community structure of a Holocene coral reef. Paleobiology 23:326-346

Ayre DJ, Dufty S (1994) Evidence for restricted gene flow in the viviparous coral Seriatopora hystrix on Australia's Great Barrier Reef. Evolution 48:1183-1201

Ayre DJ, Hughes TP, Standish RJ (1997) Genetic differentiation, reproductive mode, and gene flow in the brooding coral Pocillopora damicornis along the Great Barrier Reef. Australia. Mar Ecol Prog Ser 158:175-187

Babcock RC (1989) Fine-scale spatial and temporal patterns in coral settlement. Proc 6th Int Coral Reef Symp 2 $635-639$

Babcock RC, Mundy C (1996) Coral recruitment: consequences of settlement choice for early growth and survivorship in two scleractinians. J Exp Mar Biol Ecol 206:179-201

Baird AH, Hughes TP (1997) Spatial variation in coral recruitment around Lizard Island, Australia. Proc 8th Int Coral Reef Symp 2:1207-1211

Bak RPM, Engel MS (1979) Distribution, abundance and survival of juvenile hermatypic corals (Scleractinia) and the importance of life history strategies in the parent coral community. Mar Biol 54:341-352

Bak RPM, Meesters EH (1998) (Coral population structure: the hidden information of colony size-frequency distributions. Mar Ecol Prog Ser 162:301-306

Bak RPM. Nieuwland G (1995) Long-term change in coral communities along depth gradients over Leeward reefs in the Netherlands Antilles. Bull Mar Sci 56:609-619

Bellwood DR (1998) Fishery and reef management: response to Roberts 1997. Science 279:2021-2022

Benzie JAH, Williams ST (1997) Genetic structure of giant clam (Tridacna maxima) populations in the west Pacific is not consistent with dispersal by present-day ocean currents. Evolution 51:768-783

Benzie JAH, Haskell A, Lehman H (1995) Variation in the genetic composition of coral populations (Pocillopora damicornis and Acropora palifera) in different reef habitats. Mar Biol 121:731-739

Birkeland C (1977) The importance of rate of biomass accumulation in early successional stages of benthic communities to the survival of coral recruits. Proc 3rd Int Coral Reef Symp 1:15-21

Black KP (1993) The relative importance of local retention and inter-reefal dispersal of neutrally buoyant material on coral reefs. Coral Reefs 12:43-53

Black KP, Gay SL, Andrews JC (1990) Residence times of neutrally-buoyant matter such as larvae, sewage or nutrients on coral reefs. Coral Reefs 9:105-114

Black KP, Moran PJ, Hammond LS (1991) Numerical models show coral reefs can be self-seeding. Mar Ecol Prog Ser $74: 1-11$

Bosscher H, Meesters EH (1993) Depth related changes in the growth rate of Montastrea annularis. Proc 7 th Int Coral Reef Symp 1:507-512

Brown BE (1997) Adaptations of reef corals to physical environmental stress. Adv Mar Biol 31:221-299

Bruggeman JH, van Oppen MJH, Breeman AM (1994) Foraging by the stoplight parrotfish Sparisoma viride. l. Food selection in different socially determined habitats. Mar Ecol Prog Ser 106:41-55

Burnett WJ, Benzie JAH, Beardmore JA, Ryland JS (1994) High genetic variability and patchiness in a common Great Barrier Reef zoanthid (Palythoa caesia). Mar Biol 121:153-160

Burnett WJ, Benzie JAH, Beardmore JA, Ryland JS (1995) Patterns of genetic subdivision in populations of a clonal cnidarian, Zoanthus coppingeri, from the Great Barrier Reef. Mar Biol 122:665-673

Burrows MT, Hawkins SJ (1998) Modelling patch dynamics on rocky shores using deterninistic cellular automata. Mar Ecol Prog Ser 167:1-13

Buss LW, Jackson JBC (1979) Competitive networks: nontransitive competitive relationships in cryptic coral reef environments. Am Nat 113:223-234

Bythell JC, Bythell M, Gladfelter FH (1993a) Initial results of a long-term coral reef monitoring program: impact of Hurrucane Hugo at Buck Island Reef National Monument, St. Croix, US Virgin Islands. J Exp Mar Biol Ecol 172:171-183

Bythell JC, Gladfelter EH, Bythell M (1993b) Chronic and catastrophic natural mortality of three common Caribbean reef corals. Coral Reefs 12:143-152

Caley MJ, Carr MH, Hixon MA, Hughes TP, Jones GP, Menge BA (1996) Recruitment and the local dynamics of open marine populations. Annu Rev Ecol Syst 27:477-500

Carleton JH, Sammarco PW (1987) Effects of substratum irregularity on success of coral settlement: quantification by comparative geomorphological techniques. Bull Mar Scj 40:85-98

Carlon DB, Olson RR (1993) Larval dispersal distance as an explanation for adult spatial pattern in two Caribbean reef corals. J Exp Mar Biol Ecol 173:247-263

Carpenter RC (1986) Partitioning herbivory and its effects on coral reef algal communities. Ecol Monogr 56:345-365

Carpenter RC (1990) Mass mortality of Diadema antillarum. I. Long-term effects on sea urchin population dynamics and coral reef algal communities. Mar Biol 104:67-77

Caselle JE, Warner RR (1996) Variability in recruitment of coral reef fishes: the importance of habitat at two spatial scales. Ecology 77:2488-2504

Caswell H, Cohen JE (1993) Local and regional regulation of species-area relations: a patch-occupancy model. In: Ricklefs RE, Schluter D (eds) Species diversity in ecological communities. Chicago Univ Press, Chicago, p 99-107

Caswell H, Etter RJ (1993) Ecological interactions in patchy environments: from patch-occupancy models to cellular automata. In: Levin SA, Powell TM, Steele JH (eds) Lecture notes in biomathematics 96: Patch dynamics. Springer-Verlag, Berlin, p 93-109

Chappell J, Polach H (1991) Post-glacial sea level rise from a coral record at Huon Peninsula, Papua New Guinea. Nature 349:147-149 
Chornesky EA (1989) Repeated reversals during spatial competition between corals. Ecology 70:843-855

Clark CD (1993) Satellite remote sensing for marine pollution investigations. Mar Pollut Bull 26:357-367

Connell JH, Hughes TP. Wallace CC (1997) A 30 -year study of coral abundance, recruitment and disturbance at several scales in space and time. Ecol Monogr 67:461-488

Cornell HV, Karlson RH (1996) Species richness of reef-building corals determined by local and regional processes. J Anim Ecol 65:233-241

D'Elia CF, Wiebe WJ (1990) Biogeochemical nutrient cycles in coral reef ecosystems. In: Dubinsky Z (ed) Ecosystems of the world, Vol 25: Coral reefs. Elsevier, New York, p 49-74

De Ruyter van Stevenick ED, Bak RPM (1986) Changes in abundance of coral-reef bottom components related to mass mortality of the sea urchin Diadema antillarum. Mar Ecol Prog Ser 34:87-94

De Ruyter van Stevenick ED, Breeman AM (1987) Deep water vegetations of Lobophora variegata (Phaeophyceae) in the coral reef of Curacao: influence of grazing and dispersal on distribution patterns. Mar Ecol Prog Ser 38:241-250

De Ruyter van Stevenick ED, van Mulekom T.l.; Breeman AM (1988) Growth inhibition of Lobophora variegata (Lamouroux) Womersiey by scleractinian corals. J Exp Mar Biol Ecol 1.15:169-178

Done TJ (1992) Effects of tropical cyclone waves on ecological and geomorphological structures on the Great Barrier Reef. Cont Shelf Res 12:859-872

Done TJ, Ogden JC, Wiebe WJ, Rosen BR (1996) Biodiversity and ecosystem function of coral reefs. In: Mooney HA, Cushman JH, Medina I, Sala OE, Schulze ED (eds) Functional roles of biodiversity: a global perspective. John Wiley and Sons Ltd, New York, p 393-429

Dubinsky Z (ed) (1990) Ecosystems of the world, Vol 25: Coral reefs. Elsevier, New York

Edmunds PJ, Bruno JF (1996) The importance of sampling scale in ecology: kilometer-wide variation in coral reef communities. Mar Ecol Prog Ser 143:165-171

Edmunds PJ, Witman JD (1991) Effect of hurricane Hugo on the primary framework of a reef along the south shore of St. John, US Virgin Islands. Mar Ecol Prog Ser 78:201-204

Fisk DA, Harriot VJ (1990) Spatial and temporal variation in coral recruitment on the Great Barrier Reef: implications for dispersal hypotheses. Mar Biol 107:485-490

Foster SA (1987) The relative impacts of grazing by Caribbean coral reef fishes and Diadema: effects of habi-tat and surge. J Exp Mar Biol Ecol 105:1-20

Gaines SD, Lafferty KD (1995) Modelling the dynamics of marine species; the importance of incorporating larval dispersal. In: McEdward L (ed) Ecology of marine invertebrate larvae. CRC Press, New York, p 389-412

Gao L, Mooers CNK (1996) Numerical simulation of the IntraAmericas Sea. II. EOS Trans Am Geophys Union 76 : $142-143$

Gilpin ME, Hanski I (eds) (1991) Metapopulation dynamics: empirical. and theoretical investigations. Cambridge Univ Press, Cambridge

Gleason MG (1996) Coral recruitment in Moored, French Polynesia: the importance of patch type and temporal variation. J Exp Mar Biol Ecol 207:79-101

Goreau TJ, Macfarlane A (1990) Reduced growth rate of Montastrea annularis following the 1987-1988 coral bleaching event. Coral Reefs 8:211-216

Grosberg RK, Levitan DR (1992) For adults only? Supply-side ecology and the history of larval biology. Trends Ecol Evol $7: 130-133$

Hamner WM, Jones MS, Carleton JH, Hauri I, Williams DMcB
(1988) Zooplankton, planktivorous fish and water currents on a windward reef face: Great Barrier Reel, Australia. Bull Mar Sci 42:459-479

Hanksi I, Gilpin ME (eds) (1997) Metapopulation biology: ecology, genetics and evolution. Academic Press, San Diego

Hanski I, Simperloff D (1997) The metapopulation approach, its history, conceptual domain, and application to conservation. In: Hanski I, Gilpin ME (eds) Metapopulation biology: ecology, genetics and evolution. Academic Press, San Diego, p 5-26

Harrison PL, Wallace CC (1990) Reproduction, dispersal and recruitment of scleractinian corals. In: Dubinsky $Z$ (ed) Ecosystems of the world, Vol 25: Coral reefs. Elsevier. New York, p 133-207

Hatcher BG (1997) Coral reef ecosystem: how much greater is the whole than the sum of the parts? Coral Reefs 16 (Suppl):S77-S91

Hay ME, Taylor PR (1985) Competition between herbivorous fish and urchins on Caribbean reefs. Decologia 65: 591-598

Highsmith RC (1982) Reproduction by fragmentation in curals. Mar Ecol Prog Ser 7:207-226

Highsmith RC, Riggs AC, D'Antonio CM (1980) Survival of hurricane-generated coral fragments and a disturbance model of reef calcification/growth rates. Oecologia 46: 322-329

Highsmith RC, Lueptow RL, Schonberg SC (1983) Growth and bioerosion of three massive corals on the Belize barrier reef. Mar Ecol Prog Ser 13:261-271

Hodgson G (1985) Abundance and distribution of planktonic coral larvae in Kaneohe Bay, Oahu, Hawai. Mar Ecol Prog Ser 26:61-71

Hoegh-Guldberg O, Takabayashi M, Moreno G (1997) The impact of long-term nutrient enrichment on coral calcification and growth. Proc 8th Int Coral Reef Symp 1:861-866

Holm ER (1990) Effects of density-dependent mortality on the relationship between recrujtment and larval settlement Mar Ecol Prog Ser 60:141-146

Hubbell SP (1997) A unified theory of biogeography and relative species abundance and its application to tropical rain forests and coral reefs. Coral Reefs 16 (Suppl):S9-S21

Hudson JH, Hanson KJ, Halley RB, Kindinger JL (1994) Environmental implications of growth rate changes in Montastrea annularis: Biscayne National Park, Florida. Bull Mar Sci 54:647-669

Hughes TP (1984) Population dynamics based on individual size rather than age: a general model with a reef coral example. Am Nat 123:778-795

Hughes TP (1985) Life histories and population dynamics of early successional corals. Proc 5th Int Coral Reef Symp 5: $101-106$

Hughes TP (1989) Community structure and diversity of coral reefs: the role of history. Ecology 70:275-279

Hughes TP (1994) Catastrophes, phase shifts and large-scale degradation of a Caribbean coral reef. Science 265: $1547-1551$

Hughes TP (1996) Demographic approaches to community dynamics: a coral reef example. Ecology 77:2256-2260

Hughes TP, Connell JH (1987) Population dynamics based on size or age? A reef-coral analysis. Am Nat 129:818-829

Hughes TP, Jackson JBC (1980) Do corals lie about their age? Some demographic consequences of partial mortality, fission and fusion. Science 209:713-715

Hughes TP. Jackson JBC (1985) Population dynamics and life histories of foliaceous corals. Ecol Monogr 55:141-166

Hughes TP, Reed DC, Boyle MJ (1987) Herbivory on coral 
reefs: community structure following mass mortalities of sea urchins. J Exp Mar Biol Ecol 113:39-59

Hunte W, Wittenberg M (1992) Effects of eutrophication and sedimentation on juvenile corals: II. Settlement. Mar Biol 114:625-631

Huston M (1985) Variation in coral growth rates with depth at Discovery Bay, Jamaica (West Indies). Coral Reefs 4:19-26

Iwasa Y, Roughgarden J (1986) Interspecific competition among metapopulations with space-limited subpopulations. Theor Popul Biol 30:194-214

Jackson JBC, Hughes TP (1985) Adaptive strategies of coral reef invertebrates. Am Sci 73(3):265-274

Jackson JBC, Budd AF, Pandolfi JM (1996) The shifting balance of natural communities? In: Jablouski D. Erwin DH, Lipps JH (eds) Evolutionary paleobiology. Univ Chicago, Press, Chicago, p 89-122

Johnson CR, Preece AJ (1993) Damage, scale and recovery in model coral communities: the importance of system state. Proc 7th Int Coral Reef Symp, Guam 1:606-615

Johnson CR, Klumpp DW, Field J, Bradbury RH (1995) Carbon flux on coral reefs: effects of large shifts in community structure. Mar Ecol Prog Ser 126:123-143

Judson OP (1994) The rise of the individual-based model in ecology. Trends Ecol Evol 9:9-14

Karlson RH, Buss LW (1984) Competition, disturbance and local diversity patterns of substratum-bound clonal organisms: a simulation. Ecol Model 23:243-255

Karlson RH, Cornell HV (1998) Scale-dependent variation in local vs. regional effects on coral species richness. Ecol Monogr 68:259-274

Karlson RH, Jackson JBC (1981) Competitive networks and community structure: a simulation study. Ecology 62: $670-678$

Knowlton $N$ (1992) Thresholds and multiple stable states in coral reef community dynamics. Am Zool 32:674-682

Kojis BL, Quinn BJ (1984) Seasonal and depth variation in fecundity of Acropora palifera at two reefs in Papua New Guinea. Coral Reefs 3:165-72

Kraines SB, Yanagi T, Isobe M, Komiyama $H$ (1998) Windwave driven circulation on the coral reef at Bora Bay, Miyako Island. Coral Reefs 17:133-143

Lang JC, Chornesky EA (1990) Competition between scleractinian reef corals - a review of mechanisms and effects. In: Dubinsky Z (ed) Ecosystems of the world, Vol 25: Coral reefs. Elsevier, New York, p 209-252

Lapointe BE (1997) Nutrient thresholds for bottom-up control of macraalgal blooms on coral reefs in Jamaica and southeast Florida. Limnol Oceanogr 42:1119-1131

Lee TN, Clarke ME, Williams E, Szmant AF, Berger T (1994) Evolution of the Tortugas gyre and its influence on recruitment in the Florida Keys. Bull Mar Sci 54:621-646

Lessios HA (1988) Mass mortality of Diadema antillarum in the Caribbean: what have we learned? Annu Rev Ecol Syst 19:371-393

Lessios HA, Robertson DR, Cubit JD (1984) Spread of Diadema mass mortality through the Caribbean. Science $226: 335-337$

Levin SA (1992) The problem of pattern and scale in ecology Ecology 73:1943-1967

Levins R (1970) Extinction. Lect Math Life Sci 2:75-107

Levitan DR (1988) Algal-urchin biomass responses following mass mortalities of Diadema antillarum at St. John, US Virgin Islands. J Exp Mar Biol Ecol 119:167-178

Lewis JB (1974) The settlement behaviour of planulae larvae of the hermatypic coral Favia fragum (Esper). J Exp Mar Biol Ecol 15:165-172

Lindquist N, Hay ME (1996) Palatability and chemical defenses of marine invertebrate larvae. Ecol Monogr 66 : $431-450$

Lirman D, Fong $P$ (1997) Susceptibility of coral communities to storm intensity, duration, and frequency. Proc 8 th Int Coral Reef Symp 1:561-566

Littler MM, Littler DS, Lapointe BE (1993) Modification of tropical reef community structure due to cultural eutrophication: the southwest coast of Martinique. Proc 7 th Int Coral Reef Symp 1:335-343

Maida M, Coll JC, Sammarco PW (1994) Shedding new light on scleractinian coral recruitment. J Exp Mar Biol Ecol 180:189-202

Maida M, Sammarco PW, Coll JC (1995) Effects of soft corals on scleractinian coral recruitment. I: Directional allelopathy and inhibition of settlement. Mar Ecol Prog Ser 121. $191-202$

Man A, Law R, Polunin NVC (1995) Role of marine reserves in recruitment to reef fisheries: a metapopulation model. Biol Conserv 71:197-204

Massel SR, Done TJ (1993) Effects of cyclone waves on massive coral assemblages on the Great Barrier Reef: meteorology, hydrodynamics and demography. Coral Reefs 12 . $153-166$

McGuire MP, Szmant AM (1997) Time course of physiological responses to $\mathrm{NH}_{4}$ enrichment by a coral-zooxanthellae symbiosis. Proc 8th Int Coral Reef Symp 1:909-914

McManus JW, Ablan MC (1997) Reefbase: a global database on coral reefs and their resources. International Center for Living Aquatic Resources Management, Manila

Meesters EH, Wesseling I, Bak RPM (1997) Coral colony tissue damage in six species of reef-building corals: partial mortality in relation with depth and surface area. J Sea Res 37:131-144

Mooers CNK, Maul GA (1998) Intra-Americas sea circulation. In: Robinson AR, Brink KH (eds) The sea, Vol 11 John Wiley and Sons, Inc, New York, p 183-208

Morse DE, Hooker N, More ANC, Jensen RA (1988) Control of larval metamorphosis and recruitment in sympatric agariciid corals. J Exp Mar Biol Ecol 116:193-217

Mumby PJ, Harborne AR (1999) Development of a systematic classification scheme of marine habitats to facilitate regional management and mapping of Caribbear coral reefs. Biol Conserv 88:155-163

Mumby PJ, Green EP, Edwards AJ, Clark CD (1997) Coral reef habitat-mapping: how much detail can remote sensing provide? Mar Biol 130:193-202

Nee S, May RM (1992) Dynamics of metapopulations: habitat destruction and competitive coexistence. J Anim Ecol 61 $37-40$

Neigel JE, Avise JC (1983) Clonal diversity and population structure in a reef-building coral, Acropora cervicornis, self-recognition analysis and demographic interpretation. Evolution 37:437-453

Nowlis JS, Roberts CM, Smith AH, Sirila E (1997) Humanenhanced impacts of a tropical storm on nearshore coral reefs. Ambio 26:515-521

Ogden JC (1997) Marine managers look upstream for connections. Science 278:1414-1415

Ogden JC and 40 others (1997) Caribbean coastal marine productivity (CARICOMP): a research and monitoring network of marine laboratories, parks, and reserves. Proc 8th Int Coral Reef Symp 1:641-646

Olson RR (1985) The consequences of short-distance larval dispersal in a sessile marine invertebrate. Ecology 66: $30-39$

Opitz S (1996) Quantitative models of trophic interactions in Caribbean coral reefs. Tech Rep 43, ICLARM, Manila 
Palumbi SR (1994) Genetic divergence, reproductive isolation and marine speciation. Annu Rev Ecol Syst 25:547-572

Possingham HP, Roughgarden J (1990) Spatial population dynamics of a marine organism with ci complex life cycle. Ecology 71:973-985

Preece AL, Johnson CR (1993) Recovery of model coral com. munities: complex behaviours from interaction of parameters operating at different spatial scale's. In: Green DG, Bossomaier $\mathrm{T}$ (eds) Complex systems: from biology to computation. IOS Press, Amsterdam, p 69-81

Richmond RH (1988) Competency and dispersal potential of planula larvae of a spawning versus a brooding coral. Proc 6th Int Coral Reef Symp 2:827-831.

Roberts CM (1997) Connectivity and management of Caribbean coral reefs. Science 278:1454-1457

Rogers CS (1993) Hurricanes and coral reefs: the intermediate disturbance hypothesis revisited. Coral Reefs 12: $127-137$

Rogers CS, Fitz HC III, Gilnack M, Beets J, Hardin J (1984) Scleractinian coral recruitment patterns at Salt River Submarine Canyon, St. Croix, U.S. Virgin Islands. Coral Reefs 3:69-76

Rogers CS, Garrison V, Grober-Dunsmore R (1997) A fishy story about hurricanes and herbivory: seven years of research on a reef in St. John, US Virgin Islands. Proc 8th Int Coral Reef Symp 1:555-560

Roughgarden J, Iwasa Y (1986) Dynamics of a metapopulations with space-limited subpopulations. Theor Popul Biol 29:235-261

Rylaarsdam KW (1983) Life histories and abundance patterns of colonial corals on the Jamaican reefs. Mar Ecol Prog Ser 13:249-260

Sale PF, Cowen RK (1998) Fishery and reef management: response to Roberts 1997. Science 279:2022

Sammarco PW (1980) Diadema and its relationship to coral spat mortality: grazing, competition, and biological disturbance. J Exp Mar Biol Ecol 45:245-272

Sammarco PW (1991) Geographically specific recruitment and post-settlement mortality as influences on coral communities: the cross-continental shelf transplant experiment. Limnol Oceanogr 36:496-514

Sammarco PW, Andrews JC (1988) Localised dispersal and recruitment in GBR corals: the helix experiment. Science 239:1422-1424

Sebens KP (1987) Competition for space: effects of disturbance and indeterminate competitive success. Theor Popul. Biol 32:430-441

Shulman MJ, Bermingham E (1995) Early life histories, ocean currents, and the population genetics of Caribbean reef fishes. Evolution 49:897-910

Smith SR (1.992) Patterns of coral recruitment and post-settlement mortality on Bermuda's reefs: comparisons to the Caribbean and Pacific reefs. Am Zool 32:663-673

Smith SR (1997) Patterns of coral settlement, recruitment and juvenile mortality with depth at Conch Reef, Florida. Proc 8th Int Coral Reef Symp 2:1197-1202

Soong K (1993) Colony size as a species character in massive reef corals. Coral Reefs 12:77-83

Soong K, Lang JC (1992) Reproductive integration in reef corals. Biol Bull (Woods Hole) 183:418-431.

Spalding MB, Grenfell AN (1997) New estimates of global. and regional coral reef areas. Coral Reefs 16:225-230

Steneck RS (1989) Herbivory on coral reefs: a synthesis. Proc 6 th Int Coral Reef Symp 1:37-49

Steneck RS (1993) Is herbivore loss more damaging to reefs than hurricanes? Case studies from two Caribbean reef systems (1978-1988). In: Ginsburg RN (compiler) Global aspects of coral reefs. University of Miami, Miami, p $220-226$

Steneck RS, Dethier MN (1994) The structure of algal-dominated communities: a functional group approach. Oikos 69:476-498

Steven ADL, Broadbent AD (1997) Growth and metabolic responses of Acropora palifera to long term nutrient enrichment. Proc 8th Int Coral Reef Symp 1:867-872

Stone L (1995) Biodiversity and habitat destruction: a comparative study of model forest and coral reef ecosystems. Proc R Soc Lond Ser B Biol Sci 261:381-388

Stone L, Eilam E, Abelson A, Ilan M (1996) Modelling coral reef biodiversity and habitat destruction. Mar Ecol Prog Ser 134:299-302

Szmant AM (1986) Reproductive ecology of Caribbean reef corals. Coral Reefs 5:43-54

Szmant AM (1991) Sexual reproduction by the Caribbean reef corals Montastrea annularis and Montastrea cavernosa. Mar Ecol Prog Ser 74:13-25

Szmant-Froelich A (1985) The effect of colony size on the reproductive ability of the Caribbean coral Montastrea annularis (Ellis and Solander). Int Assoc Biol Oceanogr 6 : 295-300

Tanner JE (1995) Competition between scleractinian corals and macroalgae: an experimental investigation of coral growth, survival and reproduction. J Exp Mar Biol Ecol 190:151-168

Tilman D, May RM, Lehman CL, Nowak MA (1994) Habitat destruction and the extinction debt. Nature 371:65-66

Tomascik T, Sander F (1985) Effects of eutrophication on reefbuilding corals: I. Growth rate of the reef-building coral Montastrea annularis. Mar Biol 87:143-156

Tomascik T, Sander F (1987) Effects of eutrophication on reefbuilding corals. III. Reproduction of the reef-building coral Porites pontes. Mar Biol 94:77-94

Treml E, Colgan M, Keevican M (1997) Hurricane disturbance and coral reef development: a geographic information system (GIS) analysis of 501 years of hurricane data from the Lesser Antilles. Proc 8th Int Coral Reef Symp 1: $541-546$

van Moorsel GWNM (1988) Early maximum growth of stony corals (Scleractinia) after settlement on artificial substrata on a Caribbean reef. Mar Ecol Prog Ser 50:127-136

Victor BC (1986) Larval settlement and juvenile mortality in a recruitment-limited coral reef fish population. Ecol Monogr 56:145-160

Ward S, Harrison PL (1997) The effects of elevated nutrient levels on settlement of coral larvae during the ENCORE experiment, Great Barrier Reef, Australia. Proc 8th Int Coral Reef Symp 1:891-896

Warner RR, Hughes TP (1989) The population dynamics of reef fishes. Proc 6th Int Coral Reef Symp 1:149-155

Westneat M, Resing JM (1988) Predation on coral spawn by planktivorous fish. Coral Reefs 7:89-92

Wilkinson CR (1987) Interocean differences in size and nutrition of coral reef sponge populations. Science 236 $1654-1657$

Willis BL, Oliver JK (1988) Inter-reef dispersal of coral larvae following the annual mass spawning on the Great Barrier Reef. Proc 6th Int Coral. Reef Symp 2:853-859

Witman JD (1992) Physical disturbance and community structure of exposed and protected reefs: a case study from St John, US Virgin Islands. Am Zool 32:641-654

Woodley JU and 19 others (1981) Hurricane Allen's impact on Jamaican coral reefs. Science 214:749-755

Woodley JD and 28 others (1997) CARICOMP monitoring of coral reefs. Proc 8th Int Coral Reef Symp 1:651-656 